\title{
Clarification on the site at Byzantine and Early Islamic Khirbet Dayr-Sharaf, Neapolis, Palestine \\ El estado de la cuestión de Khirbet Dayr-Sharaf en las épocas bizantina e islámica. Neapolis (Palestina)
}

Loay Abu Alsaud,

Assistant Professor of Archaeology in An-Najah National University, Department of Tourism and Archaeology, Nablus, Palestine.

loayabualsaud@najah.edu

Recibido 20/10/2015

Aceptado 06/10/2016

\begin{abstract}
Resumen
Este estudio tiene como objetivo arrojar luz sobre el más importante de los sitios arqueológicos de la zona de Nablus (Palestina), que indica la presencia de los samaritanos en la campiña de Nablus durante las épocas bizantina y omeya. Para realizar este estudio hemos recopilado toda la información y documentación acerca de las ruinas del monasterio de Dayr Sharaf a través de las siguientes fuentes: 1) Descripción arquitectónica de los restos y evidencias arqueológicas que se encuentran sobre la superficie del terreno en el sitio arqueológico. 2) Estudio de las fuentes literarias. 3) Estudio y análisis de los grabados e inscripciones escritas descubiertos en el sitio. La sinagoga samaritana no es la única de la región, sino que hay varias más, dispersas en diferentes zonas de la campiña de Nablus. Para llevar a cabo la documentación del sitio arqueológico estudiado, el investigador tendrá en cuenta que el mismo ya había sido robado anteriormente por ladrones de antigüedades. A esto se suma la falta de interés de Israel hacia el lugar porque no forma parte de su historia antigua. Este sitio se encuentra en la zona C, ya que el Acuerdo de Oslo (1993) entre Israel y la Organización para la Liberación de Palestina establece la división del suelo palestino en tres zonas (A, B, C). El monasterio de Dayr Sharaf queda en la zona C, bajo control militar israelí, lo que impide a los palestinos realizar excavaciones arqueológicas sin la conformidad de Israel, además de la imposibilidad de restaurar y administrar el sitio, así como estudiar los restos arqueológicos e investigar el lugar sin conformidad de la parte israelí. Por tanto, el sitio está en estos momentos abandonado y expuestas muchas de sus partes a la destrucción por las razones mencionadas.
\end{abstract}

Palabras clave: Sinagoga, mosaicos, inscripciones, mausoleo, conclusiones.

\begin{abstract}
The aim of this study is to provide information on the most significant archaeological site in the Nablus area, demonstrating the presence of Samaritan archaeology in the landscape surrounding the city during the Byzantine and Early Islamic periods. The study of the site had previously been based on three different sources of information, those being descriptions of archaeological ruins and findings at the site, references in literature and inscriptions engraved in stone at the site. The Samaritan synagogue is not the only one in the region, there being others in various sites in the Nablus area. In documenting the site it was necessary to bear in mind that the site had formerly been looted for antiquities, and the fact that there has been a lack of interest in the site on the part of Israel, as it does not form part of their historic tradition. In addition, the site is located in zone C according to the Oslo Agreement of 1993 between Israel and the Palestine Liberation Organization in which Palestinian lands were divided into zones A, B and C. The fact that Khirbet Dayr Sharaf is in zone C, means it comes under Israeli military control, preventing Palestinians from undertaking archaeological excavation without agreement from Israel; restoration and management of the site as well as any research or investigation of the archaeological remains also come under this ruling. Due to this, the site is currently in a state of abandonment and susceptible to further deterioration.
\end{abstract}

Key words: Synagogue, Mosaics, Inscriptions, Mausoleum, Conclusions. 


\section{LOCATION AND CHARACTERISTICS OF THE SITE}

The site is located approximately $9 \mathrm{~km}$ west of Nablus ${ }^{1}$, on the Nablus-Tull Karem road and west of the Palestinian town Dayr Sharaf ${ }^{2}$ and comprises an area of ca. 5 donum $\left(5000 \mathrm{~m}^{2}\right)$ (fig. 1, 2).

Excavation was carried out at the site in December 1990. The work was directed by Magen, $I^{3}$. One of the distinctive signs we looked for was a public building with an orientation toward Mount Gerizim ${ }^{4}$. At the western end, beyond the bounds of the site, a thick wall built of ashlars protruded about $2 \mathrm{~m}$ above ground level. The wall drew our attention both because it faced Mount Gerizim and because the mountain could be seen from there. A brief excavation revealed benches around the structure, and subsequently, a polychrome mosaic pavement came to light depicting a Holy Ark, a Table and a Menorah.

In the middle of the site the pillars of a large oil press were found (fig. 6). Near the southwestern border of the site, beyond the bounds of the settlement, a Roman mausoleum built of fine ashlars was found. The archaeological finds date mainly to the Roman-Byzantine and early Islamic periods. The site was probably an agricultural estate of the Roman period where olive oil was produced. The style and layout of the construction and the sumptuous mausoleum suggest the private estate belonged to a wealthy citizen, who lived there and built an opulent open tomb for himself and his family.

The synagogue is a long, rectangular building, with an east-west orientation facing Mount Gerizim; it consists of four divisions - a main hall, an elongated northern exedra, a paved courtyard and a type of atrium at the entrance to the synagogue. The courtyard was probably surrounded by columns. Three phases of construction can be distinguished, both in the building of the synagogue and in the mosaic.

\section{SITE HISTORY}

In general, Samaritan synagogues were built much earlier than the Jewish. Up to 70CE the Jewish community still had a temple in Jerusalem. The Samaritans had no central temple, considering the Temple of Moses to be the only true one consecrated. The earliest information on Samaritan synagogue rites - prayer, sung poems and hymns - dates from the Hellenistic period. Up to that time the congregation would most probably have gathered in public meeting places for prayer, as they were accustomed to do on Mount Gerizim every year at Passover and for Pilgrimages (Benyamim Tsedaka $)^{5}$.

During the 2nd and 3rd centuries CE, a large Samaritan settlement was built at the site - mainly using ashlar stones. The inhabitants engaged in agriculture, primarily cultivating olives for olive oil production. The oil presses found at the site, attest to the importance of the olive oil industry in the Neapolis area. The destruction of this flourishing settlement may have been a result of one of the Samaritan revolts ${ }^{6}$.

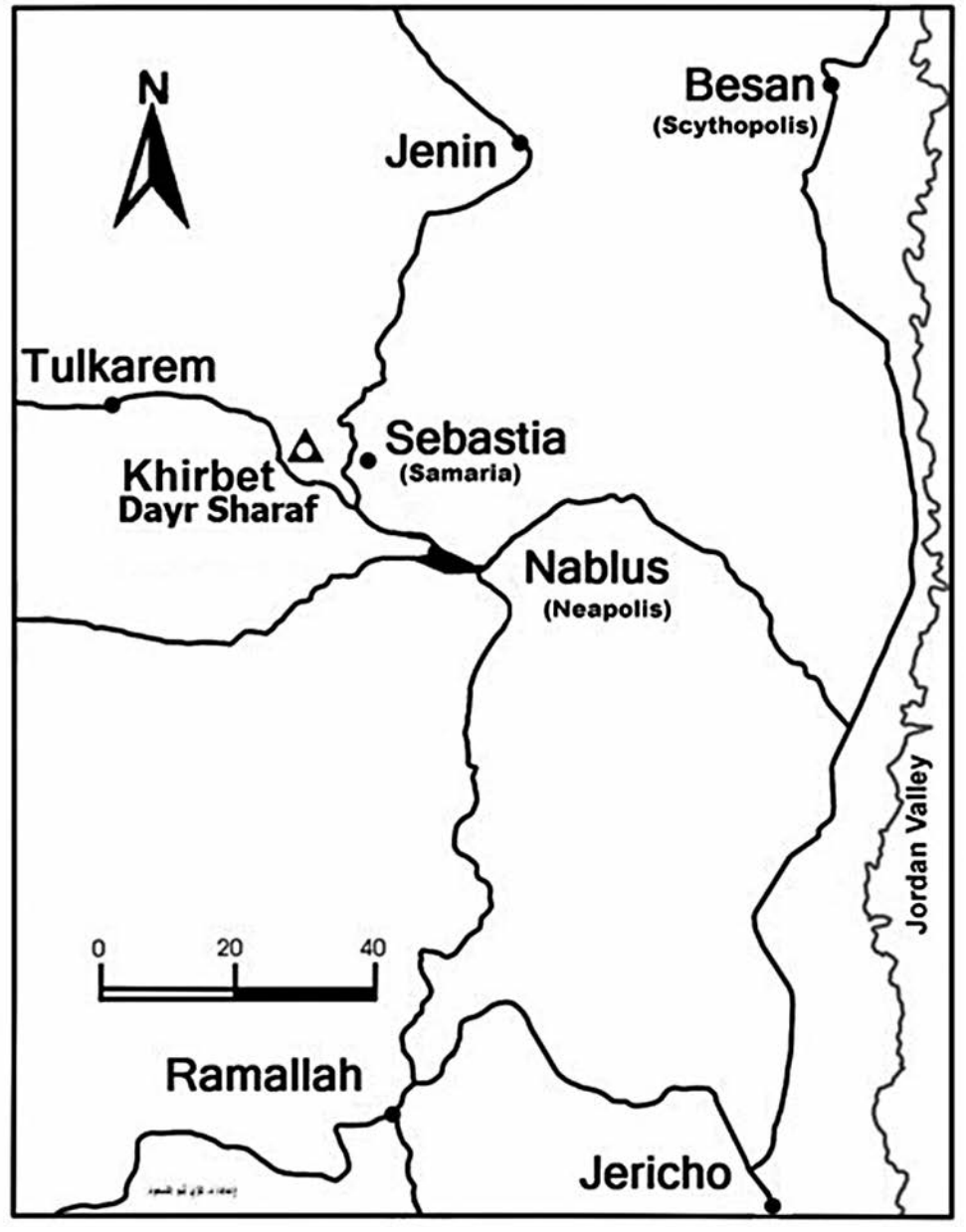

Figure 1. Map of the Nablus district and the site of Khirbet Day Sharaf.
1 www.nablus-city.net and www.pcbs.gov.ps .

2 www.wikimapia.org/3142159/shavi-shomron-synagogue .

3 Magen, I. 1991: P. 16.
4 The mount, sacred to the Samaritans, is located to the East of the Synagogue.

5 https://www.israelite-samaritans.com/religion/synagogues/

6 Magen, Y., 1993: 167. 
The main source of information is the Samaritan Chronicle, which tells of the construction of eight synagogues by Baba Rabah, a leading Samaritan figure thought to have lived in the 4th century CE. Mention of Samaritan synagogues is also made by the Byzantine writers, Epiphanius (4th century CE), Procopius of Caesarea, and John Malalas, and in the Chronicon Paschale.

During the reigns of Zeno (425-491 CE) and Justinian, the synagogue ceased to function. The Samaritans were probably under punitive control as a result of their rebellions, or were even expelled. With the end of Byzantine rule in Palestine in the 7th century $\mathrm{CE}$, the Samaritans returned to the site and restored the synagogue to use. The Samaritan settlement continued to exist in the early Islamic period.

According to a document of the Samaritan community, the Samaritans sent a group, headed by a rabbi called Sarmasa, to sign a peace agreement with Mohammed on the Arabian Peninsula. The agreement was similar to a later one of $638 \mathrm{CE}$ between the caliphate Omar and the patriarch Sophronius producing Muslim tolerance of Samaritans and Christians.

\section{MAIN HALL}

The exterior dimensions of the hall are $14 \times 12 \mathrm{~m}$, and the interior $12 \times 8.3 \mathrm{~m}$. There is a difference of ca. $40 \mathrm{~cm}$ between the lengths of the northern and southern walls. These longitudinal walls of the synagogue are particularly massive: the northern wall is $1.75 \mathrm{~m}$ wide, and the southern wall, $1.8 \mathrm{~m}$. The end walls are narrower - only $90 \mathrm{~cm}$, and the main entrance to the synagogue of one metre in width, is located on the eastern wall facing Mount Gerizim.

The doorsill consists a large reused stone, originally from an oil-press. At each end of the sill are square recesses for doorjambs.

Two tiers of bench seats were built along the inner walls of the hall. The lower tier is $60 \mathrm{~cm}$ wide and $35 \mathrm{~cm}$ high. The upper tier is somewhat narrower. Footrests were incorporated at the base of the benches. The benches surround the entire synagogue, including both sides of the entrance. On the southern side, the benches were removed, it would appear, to allow construction of a supporting wall for the synagogue ceiling. The style of the benches recalls those in a theatre. When three of the bench stones on the northern side were removed, it became clear that these were archi-

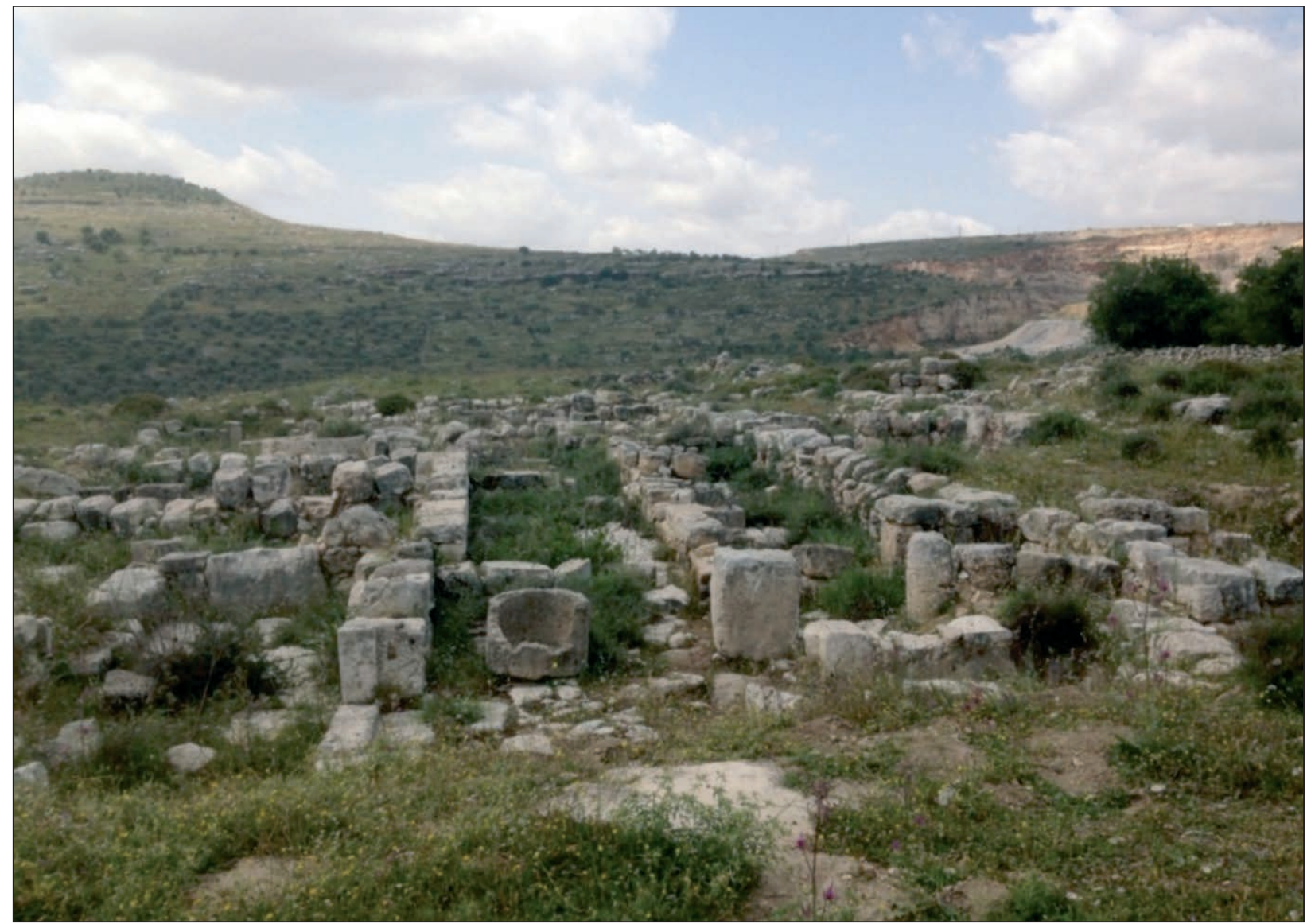

Figure 2. General view of the site. 
tectural components taken from another building - perhaps the mausoleum - and adapted to serve as seating for the synagogue. The arrangement of the benches shows that the congregation faced toward Mount Gerizim. There are square recesses in the benches on the western side, possibly for installing a fixture - perhaps a wooden Torah shrine.

\section{Main hall longitudinal Walls}

The northern wall, built with large reused ashlars, survives to a height of five courses $(2.3 \mathrm{~m})$. The wall consists of two rows of building stones filled with pebbles and poured cement. It stands on a foundation of rough fieldstones laid on bedrock. At a distance of $2.40 \mathrm{~m}$ from the north-western wall is a doorway to the northern exedra. It is $90 \mathrm{~cm}$ wide and is paved with a polychrome mosaic depicting a medallion containing an inscription. The doorway appears to have been added after construction of the synagogue, and led directly to the bench seating area. The mosaic also demonstrates a second construction phase for the building.

The southern wall is double, with the outer wall built of ashlars in the same way as the northern wall. The inner wall is the same thickness as the outer, and replaces two rows of bench seating. The construction of the additional inner wall caused damage to the edge of the mosaic pavement, which was later repaired with plaster, suggesting subsequent use of the synagogue. The barrel-vaulted roof of the synagogue seems to have become unstable or collapsed at one point, and the need had arisen to build a supporting wall in order to reduce the span of the vault.

Until now, we know of basilica style synagogues and churches in which the roof is supported by two rows of columns, but here, surprisingly, the synagogue had a barrel-vaulted roof. In the building we found about forty voussoirs of soft chalk covered with a layer of white plaster, indicating that the roof had been barrel-vaulted and that the interior of the synagogue had been plastered. The existence of a barrel-vaulted roof is also substantiated by the massive longitudinal walls needed to bear the weight of the stone vault.

\section{SyNAGOgUE COURTYARD}

The courtyard extended eastward from the synagogue and was as long as the synagogue and the northern exedra combined. We could not determine its width. The courtyard was paved with large, closely fitted stone slabs. In a number of places we could discern a type of stylobate which may possibly have served as the base for a row of columns along the façade of the synagogue, forming a narthex or peristyle.

At the north-eastern side of the courtyard, a partially plastered bench seat appears to have extended the entire length of the façade. At the northern side of the courtyard there is a row of small rooms built with reused stones. Among the stones is the base of a large pier, the base of a column, and a stone from an oil-press.

Beyond the southern wall is a courtyard paved with irregularly shaped stone slabs. It is the same length as the synagogue and $4 \mathrm{~m}$ wide. In the second phase of the building it was enclosed by a wall of fieldstones. A doorway giving access from the atrium was also built at that time.

North of the main hall is a long $2.3 \mathrm{~m}$ wide exedra, the same length as, and adjoining the synagogue. The doorway is from the east, with a well-constructed doorframe. An additional doorway led from the exedra into the synagogue.

\section{Synagogue PaVing}

The synagogue was paved with a polychrome mosaic, measuring 9x5m. (fig. 3). Tesserae were laid on a layer of white clay, over a layer of grey-black cement containing gravel. The mosaic is composed of small $8-10 \mathrm{~mm}$ square tesserae in a variety of colours. Only part of it survives; vegetation grows between the tiles. It is comprised of several sections. The central design is bordered (moving inward) by two rows of black tesserae with a thin white line between them, a row of red tesserae, a saw-tooth patterned band also in red, and a $30 \mathrm{~cm}$ wide guilloche band in black and red. Within the border is a wide band of medallions with the amount of deterioration preventing reconstruction of the design. From what little remains of the medallions, there is no evidence of human or animal representation ${ }^{7}$. Most of them seem to contain floral motifs or geometrical patterns, or depict various objects.

In the southern part of the mosaic, a branch bearing pomegranates survives; to the east of it, following an indistinct design, is an inscription in Greek. Both the pomegranates and the inscription are from the second construction phase of the synagogue.

The central mosaic is divided into three sections, two of them square and the third rectangular. The two squares, of identical size, are on the western and eastern sides, with a smaller, rectangular section between

7 This indicates that Samaritan design was influenced by the Muslim in prohibiting the representation of human and animal forms. 
them. Only a small part of the eastern square near the entrance survives. The whole may possibly have been a round sun-like motif, or a motif from the mosaic art of Palestine. The western $2.5 \mathrm{~m}$ square consists of three figure-eight intertwining rope bands, with ornamental geometric designs between the loops. In the centre is a round medallion containing an inscription in black tesserae.

Between the two squares is a $2.5 \times 1 \mathrm{~m}$ rectangle delineated with black, red and white lines. To the right is a depiction of a seven-branched Menorah. The $1 \mathrm{~m}$ high by $80 \mathrm{~cm}$ wide Menorah is rendered in white stones on a red background. The branches are made up of stylized knops and blossoms, and at the end of each branch, facing the centre, is a lamp from which a wick projects. The lamp of the central branch is particularly large. The central branch is flanked by depictions of objects resembling tongs. On both sides of the Menorah are trumpets. The foot of the Menorah does not survive in its entirety, but to the right of the stem is an inscription in white tesserae on a red background, and to the left is a large incense shovel, and the mouth and probably the neck of a type of vessel.
To the left of the Menorah is a Table. Tables from the Roman period in this form are well-known, and were apparently made of metal. Various objects are on the table: a bowl, goblets, and loaves of bread. To the left of the table is the Holy Ark with a four-column façade with a gable above with a stylized scallop-shell. Beneath it is a parokhet ${ }^{8}$ with the end looped around a column to reveal part of the door to the shrine. To the right of the Ark and above the table is another inscription, and to the left is an inscription that was added in the second construction phase.

Depiction of the Menorah and Holy Ark are seen in Jewish synagogues in Palestine; the Table is a formerly unseen element. The presence of these details in a Samaritan synagogue raises a number of questions. To this day The Samaritans use a Torah shrine with a parokhet hung in front of it. Similar symbols appear in Jewish synagogues. The question is, if the Samaritans made use of established Jewish symbols, or whether their use represents a separate and distinct Samaritan development. In either case, the Menorah, the Table of Showbread, and the Holy Ark are mentioned in the Pentateuch, which was accepted by both peoples.

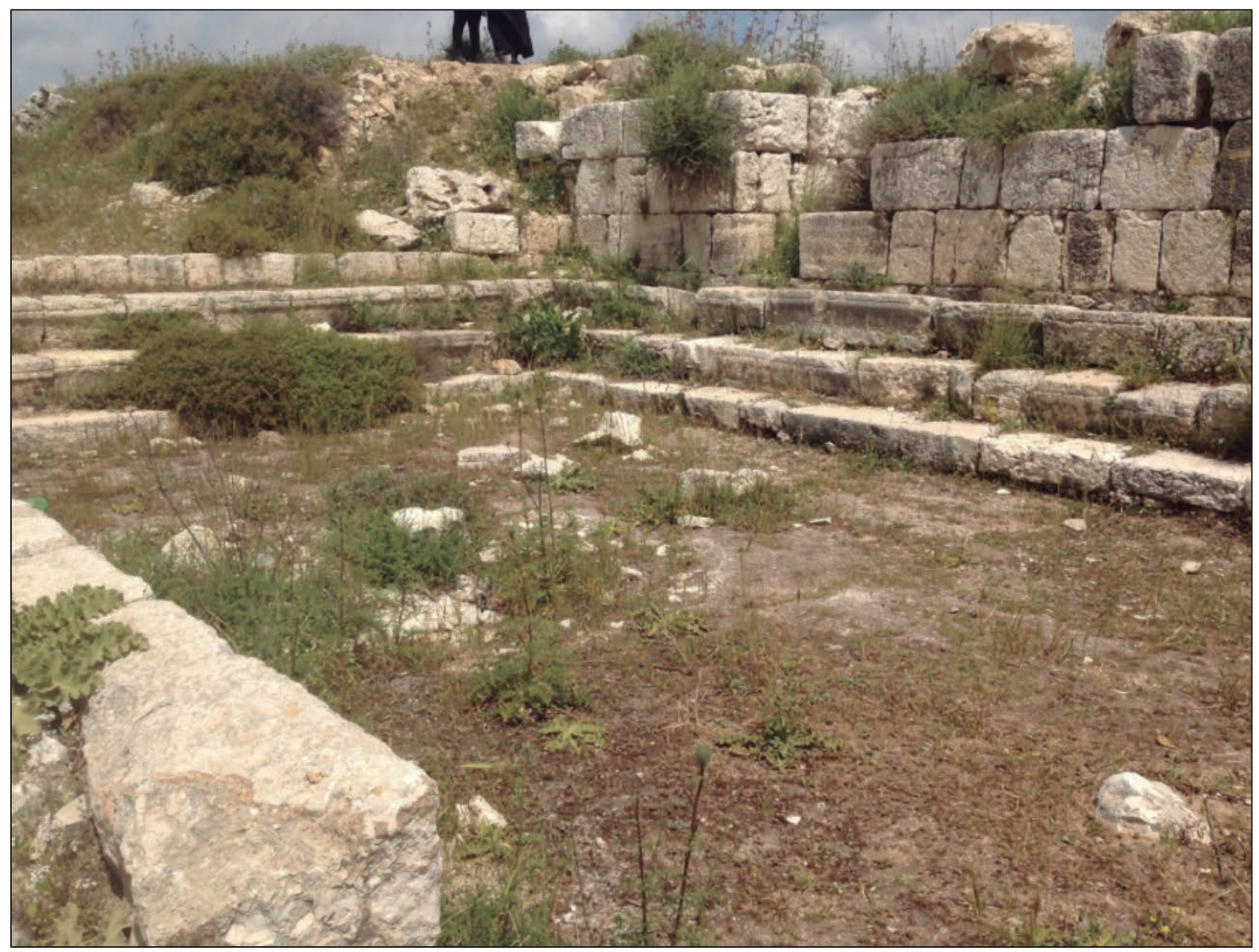

Figure 3. General view of synagogue, looking west.

8 Curtain hung in front of the Holy Ark.

9 Exodus 25: 10-40; 37: 1-24.
10 Numbers 10: 1-10.

11 Exodus 25: 31-36; 27: 17-22. 
The Book of Exodus gives precise descriptions of the Ark, the Menorah, and the Table of Showbread ${ }^{9}$. These objects of holy rites are all mentioned in the Bible in the same chapter, and therefore it is not surprising that they are depicted together. The Menorah appears together with the incense shovel and tongs, in accordance with the description in Exodus. In Jewish tradition, the Menorah appears together with the shofar, while the Samaritans probably sought to maintain the Biblical tradition of the Tabernacle, and therefore depicted two trumpets in the mosaic ${ }^{10}$, and not a shofar, which was not among the Tabernacle vessels. The branches of the Menorah reflect the Biblical description as consisting of "knops and blossoms" ne resembles a four-pillared temple, but the parokhet and the wooden door indicate that this is the Holy Ark. The Ark, the Menorah and the Table also appear on Samaritan style pottery oil-lamps.

\section{INSCRIPTIONS}

Seven inscriptions were found at the site: six appear on the mosaic paving and one is engraved in the soft limestone entrance lintel ${ }^{12}$. Three inscriptions are from the first construction phase of the synagogue; three others, of inferior execution, were added at a later stage, but they also date from the $4-5^{\text {th }}$ centuries CE. The inscriptions were translated and interpreted by Leah Di Segni ${ }^{13}$.

Inscription 1: found at the centre of the western mosaic within a round medallion of $53 \mathrm{~cm}$ in diameter. It is in Greek and written with black tesserae on a white background. The translation reads: "Prosper, Marinus, with your children."

The central location of the inscription suggests that Marinus was the main contributor to the synagogue.

Inscription 2: found between the Holy Ark and the Table, this inscription is executed with black tesserae on a white background. Most of the inscription is damaged, thereby preventing complete reconstruction. The translation of the surviving part reads: "Be exalted the great soul of Alaphion."

The name is apparently Arabic, and it may have been a memorial inscription to a deceased person.

Inscription 3: The five line inscription positioned to the right of the Menorah, is in white tesserae on a red background in the same way as the Menorah.

10 Numbers 10: 1-10.

11 Exodus 25: 31-36; 27: 17-22.

12 The inscriptions are not present on the remains of the mosaic tiled floors.
It is also in a poor state of preservation, making complete reconstruction difficult. It reads: "Be exalted Alexas the....of this place."

Inscription 4: This inscription is found on the doorway from the north exedra into the synagogue dating to a later construction phase. In red tesserae on a white background, it is positioned within a round medallion surrounded by black tesserae. The quality of execution is inferior to that of the preceding inscriptions. It reads: "Only God, help Sophronius (son) of Frotinus."

Inscription 5: Also added in a later construction phase, the inscription is located to the left of the Holy Ark. It consists of five lines written in red on a white background within a rectangular border and is partly damaged. The remaining wording reads: "Only God Help...Sintiacus (?) The (son) of Mares (?)."

Inscription 6: To the left of Inscription 5, the inscription is positioned within a band of medallions comprising the central design. The writing is in red on a white background within a square. With only part of it surviving it reads: "Only God, help Ath (emos)."

Inscription 7: This inscription is engraved in the lintel of the synagogue entrance. It is illegible, and may belong to an earlier period.

On the basis of paleographic analysis, Leah Di Segni concluded that the inscriptions date to the late 3rd or early 4th centuries. Inscriptions 4, 5 and 6 may be later. The names appearing on the inscriptions are Greek or Arabic. The presence of Greek inscriptions in Samaritan synagogues is not unusual, and is also an element of Jewish synagogues.

\section{CoIns}

Of the 49 coins found at the site, not all of them were from the synagogue; some were discovered south of it, by the mausoleum (table 1). It appears that most of the coins belonged to the synagogue precinct. Most of them date to the period in which the synagogue flourished 4-5th centuries CE. During the reigns of Zeno (476491CE) and Justinian I (527-565CE) the synagogue ceased to function. The Samaritans probably came under punitive control as a result of their rebellions, or were even expelled. With the decline of Byzantine rule in Palestine in the 7th century CE, The Samaritans returned to the site and restored the synagogue. Their settlement continued to exist into the Early Islamic period.

13 Segni, Leah Di. 1993. The Greek inscriptions in the Samaritan synagogue At El-Khirbe, with Some Considerations on the Function of the Samaritan Synagogue in the Late Roman Period. Early Christianity in Context. Pp: 231-239. 


\begin{tabular}{|c|c|c|c|}
\hline Lot & Emperor/Century & Date & Coin quantity \\
\hline 1 & Diocletian & 296 C.E. & 1 \\
\hline 2 & Constantine I & $306-337$ C.E. & 4 \\
\hline 3 & Valens & $364-367$ C.E. & 1 \\
\hline 4 & Theodosius I & $388-392$ C.E. & 1 \\
\hline 5 & Justin I & $518-527$ C.E. & 1 \\
\hline 6 & Heraclius & $625-630$ C.E. & 1 \\
\hline 7 & Constans II & $641-647$ C.E. & 1 \\
\hline 8 & 4 th century C.E. & -------- & 9 \\
\hline 9 & from the mid-5th century & -------- & 2 \\
\hline 10 & Islamic & -------- & 4 \\
\hline
\end{tabular}

Table of the coins that discovered in the site.

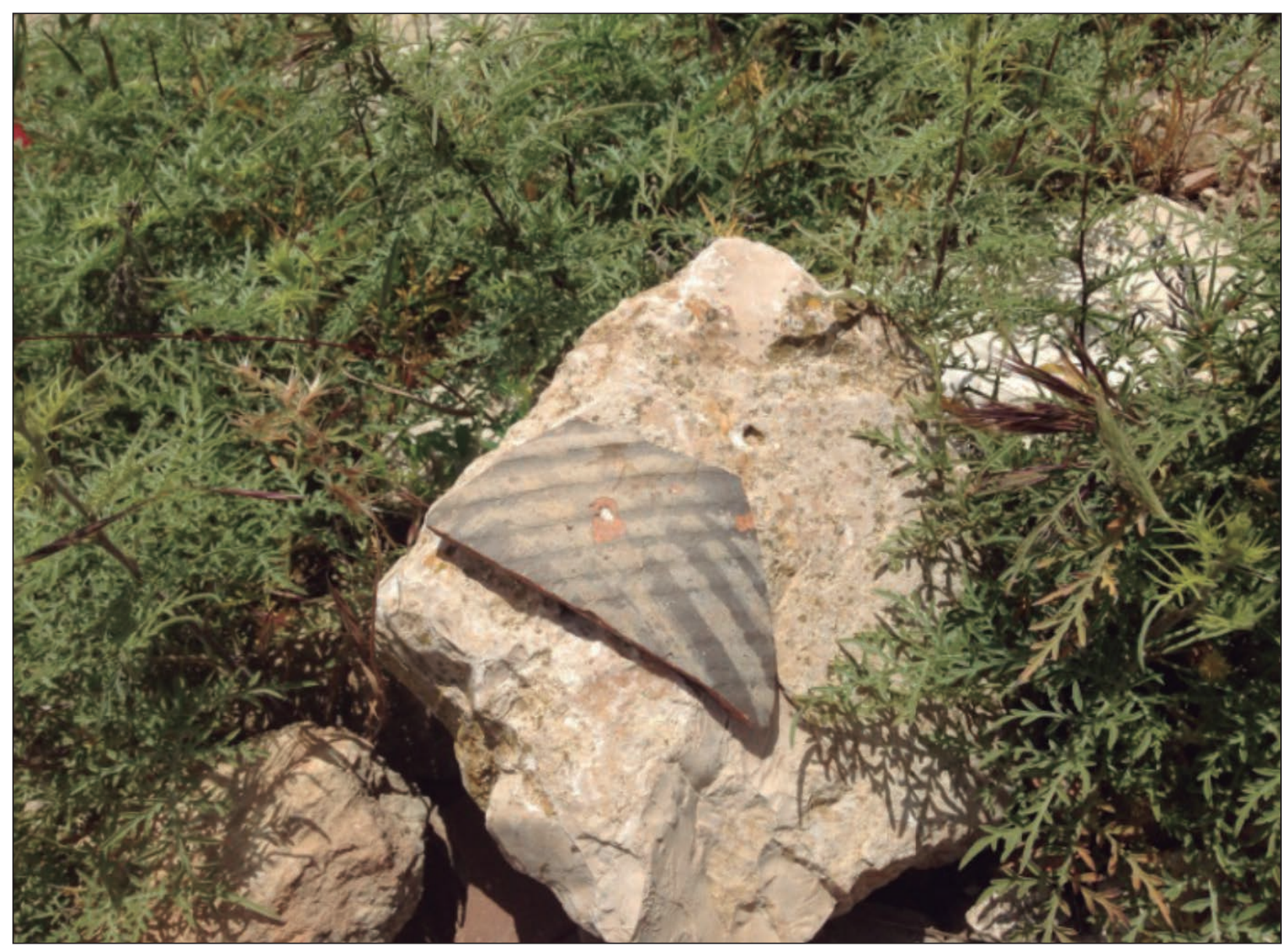

Figure 4. Postsherds of the Early Byzantine and Early Islamic Pottery in situ. 


\section{Mausoleum}

About $25 \mathrm{~m}$ south of the synagogue, a temple style Roman mausoleum, of superior ashlar construction in the Roman tradition, was uncovered (fig. 5). The building had belonged to the family of the owner of the estate, who must have resided at the site.

A repository pit dug in the pavement of the central chamber at the centre of the burial courtyard is coated with a layer of grey-black plaster. The pit was covered by a fragment of a sarcophagus lid and contained a large quantity of bones, pottery vessels, oil lamps, jars, and glass vessels. It would seem that the repository pit was dug, the sarcophagi removed, and the bones and funerary vessels collected and placed in it because the proximity of the mausoleum to the synagogue raised problems of ritual uncleanliness.

\section{Conclusion}

The synagogue appears to have been built in the 4th century CE and was in use for several decades or more. It was possibly destroyed during the Samaritan revolt of $529 \mathrm{CE}$. We can assume that the Samaritans returned to the site at the end of the Byzantine period and attempted to rebuild it, as they did with the Samaritan site at the Kofor Qadum synagogue.

The synagogue at the Khirbet Dayr-Sharaf site is the first completely intact synagogue from the 4th century CE to be uncovered in the Nablus Area. It was almost entirely built reusing stones from a nearby site. The entrance faces Mount Gerizim, which is in view from the synagogue. The building, situated outside the settlement, consisted of a rectangular main hall with a barrel-vaulted roof supported by thick walls, with bench seating lining the walls.

During its founding period in the 4th century CE, according to a ratio devised by $\mathrm{C}$. Carreras Monfort of 326 inhabitants to each hectare in an area of 5 donum $\left(1\right.$ donum $\left.=1000 \mathrm{~m}^{2}\right)$, the synagogue would have had a population of 163 . This differs somewhat from Spigel's calculations, Ch.S 2012, of 107 inhabitants in the founding period and 83 in the later period (Spigel, Ch.S.2012: 96). If we accept a population density of 3-4 families per donum (Safrai, Z., 1994: 373 ), then 15-20 families would have occupied an area of 5 donum $\left(5000 \mathrm{~m}^{2}\right)$; with an average of 5 members per family there would have been a congre-

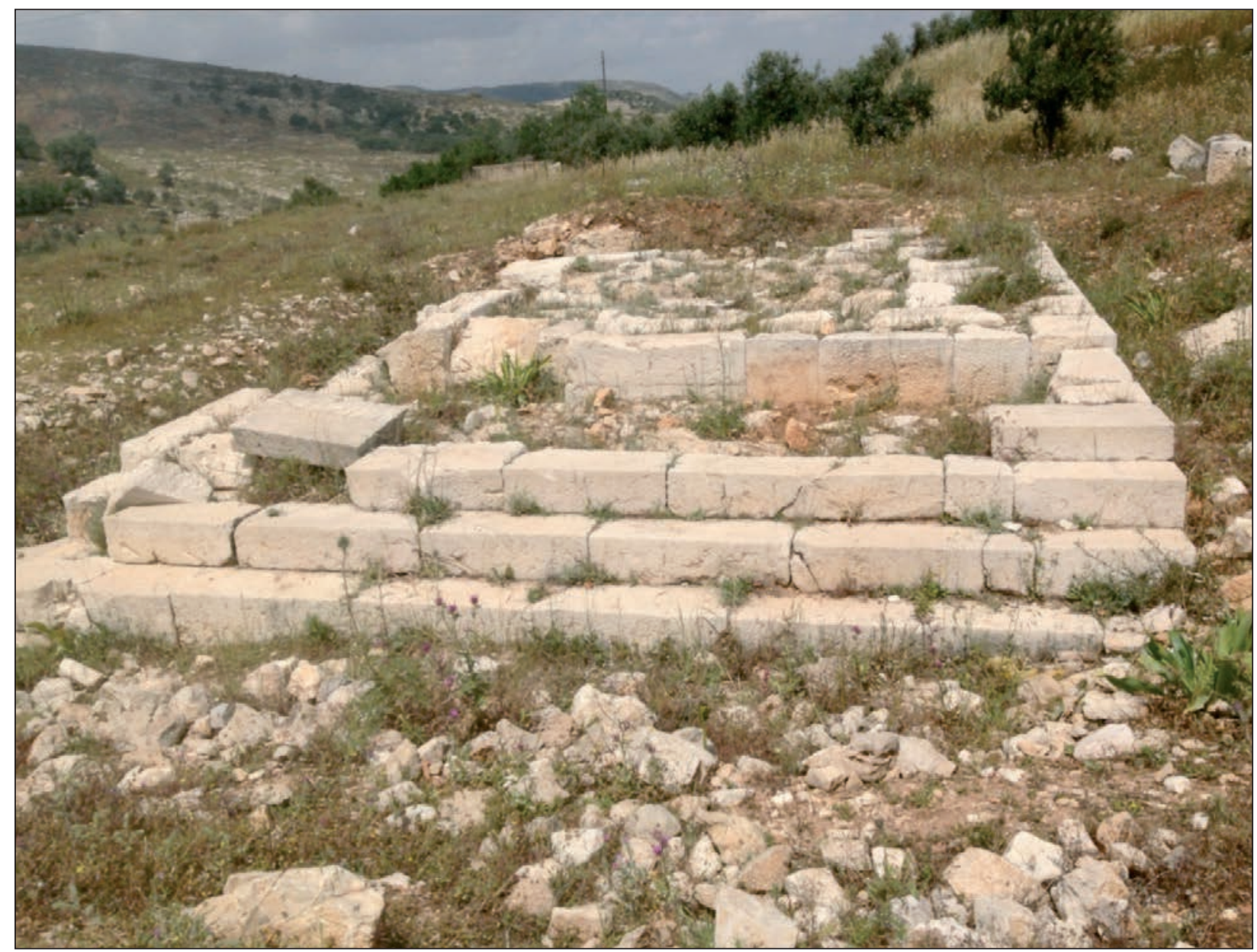

Figure 5. The mausoleum south of the site. 


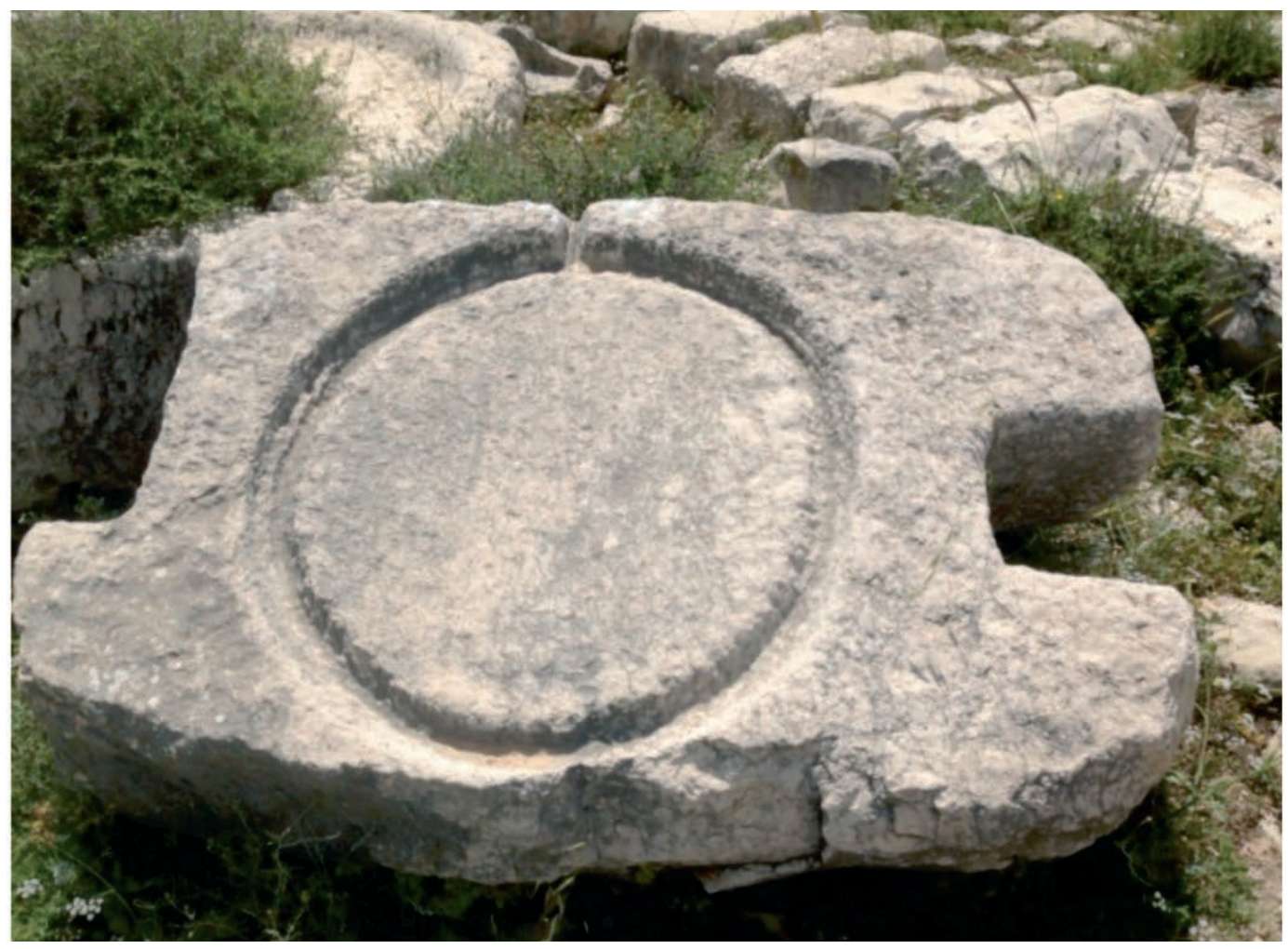

Figure 6. The Oil-press pillars.

gation of 75-100 in the 4th century founding period, a similar figure to Spigel's.

The mosaic paving, coins, and architectural style of the synagogue leave no doubt that it was built in the 4th century CE, a period in which newly built Samaritan synagogues increased in number. The building is similar to the synagogue at Khirbet Samara, and it may reasonably be assumed that it was built in a similar tradition: facing toward Mount Gerizim, situated beyond the settlement, and reusing stones from other sites. The prohibition of the depiction of human and animal forms was observed by the builders, with all decoration being floral, vegetal or geometric and only inanimate objects being depicted. Three representations of the Holy Ark were found, two in mosaic and one engraved in stone. It is probable that a Menorah would also have been represented but none survives.

Inscriptions and coins found during excavation indicate that construction of the synagogue dates to the 4 th century. Destroyed at the end of the 5th or in the 6th century during the Samaritan revolts and it was poorly restored either late in the Byzantine period or in the early Islamic period and used briefly (fig. 4).

Mosaic paving is a major innovation, being so far some of the earliest discovered in a synagogue in Palestine. The representations of the Menorah, the Table of Showbread, and the Holy Ark, until now only seen in Jewish synagogues mainly of a later date, pose many questions regarding the interrelationship between
Samaritans and Jews in the Roman-Byzantine period in matters of halakhah and ritual symbolism.

All the symbols represented in the synagogue, such as the Table of Showbread, the Menorah, and the Holy Ark, are mentioned in the Torah. The question remains whether their presence in a Samaritan synagogue is an imitation of Jewish tradition, or whether it represents an independent Samaritan tradition. Another unanswered question relates to the form the Samaritan liturgy would have taken during the period from the late 2 nd century BCE Hellenistic period until the 4th century $\mathrm{CE}$. Nor can it be determined whether the synagogue represents a development of a still undiscovered earlier structure of the Samaritan rite, or if it was an imitation of a Jewish building.

\section{REFERENCES}

Avi-Yonah, M. (1947): "Remains of an Ancient Synagogue in Kafr Fahma", Yediyot 13: 154-155 (Hebrew).

Ben-Zvi, Y. (1970): The Book of the Samaritans. Jerusalem.

Carreras Monfort, C. (1996): “Una nueva perspectiva para el studio demografico de la Hispania Romana". Boletin del Seminario de Arte y Arqueologia BSAA, LXII: 95-122.

Cowley, A.E. (1909): The Samaritan Liturgy. Oxford. 
Fine, S. (2012): Jews, Christians and Polytheists in the Ancient Synagogue. Cultural interaction during the graeco-roman period. Tübingen. Mohr Siebeck: 122-123.

Kippenberg, H.G. (1971): Gerizim und Synagogue. Berlin \&New York. https://doi.org/10.1515/978311 0828214

Levine, L.I., (1993): "Synagogue". The New Encyclopedia of Archaeological Excavations in the Holy Land. Vol.4. Jerusalem: 1421-1424.

Magen, Y. (1991): "El-Khirbe, Samaritan Synagogue". Excavations and Survey in Israel. 10. Number: 9697. Jerusalem: 16.

Magen, Y. (2008): The Samaritans and the Good Samaritan. Jerusalem: 127-142.

Magen. Y., (1993): "Samaritan Synagogues". The New Encyclopedia of Archaeological Excavations in the Holy Land. Vol.4. Jerusalem: 1424-1427.

Magen.Y., (1993): "Qedumim- A Samaritan Site of the Roman-Byzantine Period". Early Christianity in Context: Monuments and Documents. Franciscan Printing Press. Jerusalem: 167-179.
Milson, D.W. (2006): "Art and Architecture of the Synagogue in Late Antique Palestine". In the Shadow of the Church: 350-351.

Pummer, R. (1989). "The Samaritan Material Remains and Archaeology". In: Crown, A. (ed.). The Samaritans. Tübingen: 139-151.

Safrai, Z. (1977): "Samaritan Synagogues in the Roman Byzantine Period". Cathedra 4: 84-112. (Hebrew).

Safrai,Z. (1994): The economy of roman Palestine. LondonNew York. https://doi.org/10.4324/9780203204863 PMid:7940377

Segni, Leah Di. (1993): "The Greek Inscriptions in the Samaritan Synagogue At El-Khirbe, with Some Considerations on the Function of the Samaritan Synagogue in the Late Roman Period". Early Christianity in Context. Franciscan Printing Press, Jerusalem: 231-239.

Spigel, Ch. S. (2012): Ancient Synagogue Seating Capacities: Methodology, Analysis and Limits. Tübingen. 